\title{
The Development of the Quality of Indonesian Educators through Professional Teachers: A Literature Review
}

\author{
Teti Nurhidayah ${ }^{1}$, Hasan Hariri ${ }^{2}$, Riswanti Rini ${ }^{3}$, Sowiyah ${ }^{4}$, Alifa Soraya Nuryadika ${ }^{5}$ \\ ${ }^{1,5}$ Student of Education Administration, Universitas Lampung, Bandar Lampung, Indonesia \\ ${ }^{2,3,4}$ Lecturer of Education Administration, Universitas Lampung, Bandar Lampung, Indonesia
}

\begin{abstract}
The government's efforts to continue to develop the teaching profession as a strong and respected profession in line with other professions can be seen from the issuance of Law No. 14 of 2005 concerning Teachers and Lecturers who seek to develop the teaching profession through legal protection. The government has made efforts to improve the professionalism of teachers, including increasing the qualifications and requirements for higher education levels for teaching staff from the school level to tertiary institutions. Other efforts made by the government are the certification program and the establishment of the PKG (Teacher Activity Center), MGMP (Subject Teacher Consultation) and KKG (Teacher Working Group).The important thing and needs to be done by the government is to build self-reliance among teachers.
\end{abstract}

KEYWORDS: Development, Educators, Professional, Quality, Teacher

\section{INTRODUCTION}

In efforts to develop national education, teachers (educators) are urgently needed in quality standards of guaranteed competence and professionalism. To achieve the number of professional teachers who can drive the dynamics of the progress of national education, a continuous, targeted and effective development process is needed. The process of becoming a professional teacher needs to be supported by all elements related to teachers. These elements can be combined to produce a system that can automatically work towards the formation of professional teachers in sufficient quality and quantity.

In line with government policy, through Law no. 14 of 2005 article 7 mandates that the empowerment of the teaching profession is carried out through self-development that is carried out in a democratic, fair, non-discriminatory, and sustainable manner by upholding human rights, religious values, cultural values, national pluralism, and professional codes of ethics. In addition, according to article 20, in carrying out professional duties, teachers are obliged to improve and develop academic qualifications and competencies on an ongoing basis in line with the development of science, technology, and the arts.

Keeping in mind the weight and complexity of building education, it is very important to make efforts to encourage and empower educators to be more professional (Mustofa, 2007). This is nothing but intended to make efforts to build education strong, and able to continuously make improvements to a higher quality.

The professionalism of teachers and education staff is still inadequate, especially in terms of their scientific fields. For example a Biology teacher can teach Chemistry or Physics. Or social studies teachers can teach Indonesian. The quality and professionalism of teachers is not in line with expectations. Many of them are not qualified and convey the wrong material so that they are not or less able to present and provide truly quality education (Dahrin, 2000).

Education is a very important field for human life, education can encourage the improvement of human quality in the form of increasing cognitive, affective, and psychomotor competencies. (Timperley et al., 2007). The problems faced in efforts to improve and improve the quality of life are very complex, many factors must be considered because their influence on human life cannot be ignored, which is clearly realized that education is one of the factors that can improve the quality of a nation's human resources. Along with the development of the times and the era of globalization which is very fast, it demands an increase in the quality of education. Every education system must be able to do changes towards improvement and quality improvement (Goodwin \& Kosnik, 2013). In efforts to develop national education, teachers (educators) are urgently needed with guaranteed quality standards of 


\section{International Journal of Current Science Research and Review}

ISSN: 2581-8341

Volume 04 Issue 07 July 2021

DOI: 10.47191/ijcsrr/V4-i7-13, Impact Factor: 5.825

IJCSRR@ 2021

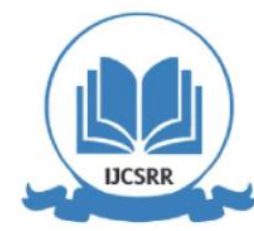

www.ijcsrr.org

competence and professionalism. To achieve the number of professional teachers who can drive the dynamics of national education progress, a continuous, targeted and effective development process is needed(Petrie \& McGee, 2012).

Moving on from the theoretical thinking above, efforts are needed to formulate policies and develop the teaching profession. That's why, lately there has been a stronger urge to review the teacher management system, especially with regard to the provision, recruitment, appointment and placement, distribution system, certification, improvement of qualifications and competencies, performance appraisal, competency testing, rewards and protection, welfare, development career, sustainable professional development, supervision of professional ethics, and teacher management in special areas relevant to current and future demands. The existence of professional and competent teachers is a must to facilitate the achievement of learning objectives. Professional teachers are able to reflect the figure of their teacher with broad insight and have a number of competencies that support their duties (Sobri, 2016) Efforts to develop teacher professionalism need to be carried out continuously so that their knowledge, understanding and skills related to their duties always follow developments in the world of education (Disas, 2017) For this purpose, the Ministry of Education and Culture always strives to improve policies in the field of coaching and developing the teaching profession.

\section{METHOD}

The method used in this study is a qualitative method, this method was chosen because it aims to determine how to find, collect, process and analyze data from the results of the study. The type of this research approach is descriptive. Descriptive research is research that seeks to describe current problem solving based on data.

The type of descriptive approach used in this research is a case study. Case studies are included in descriptive analysis research in which the research focuses on a particular case that is carefully observed and analyzed. This analysis is carried out on various factors related to the case under study, in this study the case studied was regarding the policy of developing and improving the teaching profession in order to realize the goals of national education. This research focuses intensively on policy development and improvement of the teaching profession and studies it as a case. The data taken in this study came from various sources and research results related to the case being investigated.

\section{RESULTS AND DISCUSSION}

\section{Public Policy Issues and Phenomena}

This teacher development and improvement policy has been widely discussed on the issue of enhancement and the development of the teaching profession that is now developing in the media regarding the change in the pattern of PLPG to PPG. The scope of public policy analysis (public policy analysis), the meaning contained in the term "issue" is not what is generally understood by ordinary people in everyday conversation (Wahab, 2012). So in essence, policy issues usually arise because there have been disagreements among stakeholders regarding the direction of action that has been or will be taken, or conflicting views regarding the character of the problem itself.

\section{Public Policy Analysis}

Policy analysis is an applied social research that is systematically arranged in order to find out the substance of the policy so that information can be clearly identified regarding the problems answered by the policy and the problems that may arise as a result of the implementation of the policy. The scope and methods of policy analysis are generally descriptive and factual regarding the causes and effects of a policy that public policy refers to all areas of government action that stretches from economic policy to policies that usually refer to social policies including education, health, and regional other welfare.(Fattah, 2016) that education policy analysis describes how the State plans and leads to education priorities, then the results of the analysis must be explained by the existence of global policy factors.

Policy analysis is an applied social science discipline that uses a variety of research methods and arguments to generate and transmit policy-relevant information, so that it can be utilized at the political level in order to solve policy problems.(Dunn, 2015). The product of policy analysis is advice. Specifically, it is advice that informs some public policy decision (Mead, 2013). So public policy analysis is more of an advice or consideration for public policy makers which contains the problems faced, the tasks that must be 


\section{International Journal of Current Science Research and Review}

ISSN: 2581-8341

Volume 04 Issue 07 July 2021

DOI: 10.47191/ijesrr/V4-i7-13, Impact Factor: 5.825

IJCSRR@ 2021

Www.ijcsrr.org

carried out by public organizations related to these problems, and also various alternative policies that might be taken with various assessments based on policy objectives.

Public policy analysis aims to provide recommendations to assist policy makers in solving public problems (Hanushek, 2005). In the analysis of public policy there is information related to public problems as well as arguments about various policy alternatives, as material for consideration or input to policy makers.

\section{Teacher Professionalism Concept}

The word professionalism comes from the English word 'profession' which means work. According to Kunandar (2007) the teaching profession is special expertise and authority in the fields of education, teaching, and training that is occupied to become a livelihood in meeting the needs of the person concerned. Usman (2006) defines a professional teacher as a person who has special abilities and expertise in the field of teaching so that he is able to carry out his duties and functions as a teacher with maximum abilities. In line with Usman, Sudrajat (2013) argues that professional teachers are teachers who have qualified abilities in carrying out their duties as teachers.

Teachers are said to be professional if they have professional abilities in the field of learning, namely: the ability to carry out their roles as facilitators, mentors, environmental providers, models, motivators, agents of cognitive development and managers. Furthermore, they explain the three criteria attached to professional teachers, namely: personal piety, social sensitivity and scientific integrity (Jihad, 2013).

Teacher professionalism certainly cannot be separated from the activities of teacher professional development itself. Broadly speaking, teacher professional development activities can be divided into three parts, namely: (1) intensive development, (2) cooperative development, and (3) self-directed development (Sudrajat, 2013).

Intensive development (intensive development) is a form of development carried out by the leadership of the teacher which is carried out intensively based on the needs of the teacher. This model is usually carried out through systematic steps, from planning, implementation, to evaluation and feedback or reflection meetings. The development techniques used include training, upgrading, courses, workshops, and the like.

Cooperative development (cooperative development) is a form of teacher development that is carried out in collaboration with colleagues in a team that works together systematically. The goal is to improve the professional abilities of teachers through providing input, suggestions, advice, or peer assistance. The development technique used can be through KKG or MGMP/MGBK meetings. This technique is also known as peer supervision or collaborative supervision.

Self-directed development is a form of development that is carried out through self-development. This form gives broad autonomy to the teacher. Teachers try to plan activities, carry out activities, and analyze feedback for self-development. The technique used can be through self-evaluation or action research.

Regarding teacher professional development efforts, Harris (2001) argues that an effective teacher professional development effort is an effort that provides opportunities for teachers to play their roles both as teachers and learners. These efforts include teaching, assessment, observation, reflection which are characteristics of learning and developmental processes. From the description above, it is clear that the role of the teacher as a learner is very important in the development of the teaching profession. Furthermore, the concept of teacher learning will be discussed in relation to teacher professionalism.

\section{Teacher Professional Development Strategy}

The development of teacher professionalism is a global concern, because teachers have the task and role of not only providing scientific and technological information, but also forming attitudes and souls that are able to survive in the era of hyper competition (Danim, 2012). The task of the teacher is to help students to be able to adapt to the various challenges of life and the pressures that develop within them. The empowerment of these learners includes aspects of personality, especially intellectual, social, emotional, and skill aspects. This noble task becomes difficult because not only teachers must prepare the younger generation to enter the age of knowledge, but also must prepare themselves to exist, both as individuals and as professionals.

Developing the teaching profession is not something easy. This is due to many factors that can affect it (Hasanah, 2012). Therefore, it is important to pay attention to the environment in which the development is carried out, especially if these factors can hinder 


\section{International Journal of Current Science Research and Review}

ISSN: 2581-8341

Volume 04 Issue 07 July 2021

DOI: 10.47191/ijcsrr/V4-i7-13, Impact Factor: 5.825

IJCSRR @ 2021

www.ijcsrr.org

efforts to develop the teaching profession. In this connection, bureaucratic factors, especially the education bureaucracy, are often lacking/not supportive of creating a conducive atmosphere for the development of the teaching profession.

Other dimensions of the pattern of teacher professional development are (1) the close relationship between higher education institutions and senior high school development; (2) improve the form of recruitment of prospective teachers; (3) upgrading program related to field practice; (4) improve the quality of teacher candidate education; (5) implementation of supervision; (6) improving the quality of education management based on Total Quality Management (TQM); (7) involving community participation based on the concept of link and match; (8) empowerment of text books and supporting educational tools; (9) public recognition of the teaching profession; (10) the need for confirmation of the Teaching Deed program through laws and regulations; and (11) positive professional competition with the provision of proper welfare (Wahyudi, 2016).

\section{Government Efforts to Improve Teacher Professionalism}

The government has made efforts to improve the professionalism of teachers. These efforts are carried out by increasing the qualifications and requirements for higher education levels for teaching staff from the school level to tertiary institutions. Diploma II equalization program for elementary school teachers, Diploma III for junior high school teachers and Strata I (bachelor) for senior high school teachers. However, this equalization does not mean much, if the teacher lacks the power to make changes.

In addition to holding equalization of teachers, another effort made by the government is a certification program according to the mandate of Law no. 14 of 2005 article 42. In addition to certification, other efforts have been made in Indonesia to improve teacher professionalism, for example by activating the PKG (Teacher Activity Center, MGMP (Subject Teacher Conference), and KKG (Teacher Working Group) which allows teachers to share experience in solving the problems they face in their teaching activities.

Professionalization should be viewed as a continuous process (Ariyani, 2017). In this process, pre-service education, in-service education including upgrading, guidance from professional organizations and workplaces, community appreciation for the teaching profession, enforcement of professional codes of ethics, certification, improvement of the quality of teacher candidates and welfare together determine professional development. Thus, efforts to improve teacher professionalism are a shared responsibility between LPTKs as teacher producers, agencies that develop teachers (in this case the Ministry of National Education or private foundations), PGRI and the community.

Of the several efforts that have been made by the government above, the most important factor so that teachers can improve their qualifications is to equalize the number of working hours with teacher salaries. Whatever program the government will implement, but if teacher salaries are low, it is clear that to meet their daily needs the teacher will look for additional work to meet their needs.

\section{CONCLUSION}

The teaching profession is a very important profession in the life of a nation. Teachers are the dominant element in an educational process, so the quality of education is largely determined by the quality of educators in carrying out their roles and duties in society. Therefore, efforts to continue to develop the teaching profession are an absolute requirement for the progress of a nation. Increasing the quality of educators will encourage the improvement of the quality of education, both process and results.

The government's efforts to continue to develop the teaching profession as a strong and respected profession in line with other professions can be seen from the issuance of Law No. 14 of 2005 concerning Teachers and Lecturers who seek to develop the teaching profession through legal protection. The government has made efforts to improve the professionalism of teachers, including increasing the qualifications and requirements for higher education levels for teaching staff from the school level to tertiary institutions. Diploma II equalization program for elementary school teachers, Diploma III for junior high school teachers and Strata I (bachelor) for senior high school teachers. Other efforts made by the government are the certification program and the establishment of the PKG (Teacher Activity Center and KKG (Teacher Working Group)), in addition to improving welfare by seeking teacher professional allowances.

In the development of the teaching profession, the important thing is to build independence among teachers so that they can be better able to actualize themselves in order to realize quality education. 


\section{International Journal of Current Science Research and Review}

ISSN: 2581-8341

Volume 04 Issue 07 July 2021

DOI: 10.47191/ijesrr/V4-i7-13, Impact Factor: 5.825

IJCSRR@ 2021

Www.ijcsrr.org

\section{REFERENCES}

1. Ariyani, R. (2017). Principal leadership in teacher professional development. Al-Afkar Journal, 5(1).

2. Dahrin, D. (2000). Improving National Education Performance Comprehensively: Education Transformation. Community, Indonesian Chancellor's Forum, 1.

3. Danim, S. (2012). Teacher Professional Development. Jakarta: Prenada Media.

4. Disas, EP (2017). Education policy analysis regarding the development and improvement of the teaching profession. Journal of Educational Research, 17(2).

5. Dunn, WN (2015). Public policy analysis. Routledge.

6. Fattah, N. (2016). Educational Management Foundation. Bandung: Rosdakarya Youth.

7. Goodwin, AL, \& Kosnik, C. (2013). Quality teacher educators= quality teachers? Conceptualizing essential domains of knowledge for those who teach teachers. Teacher Development, 17(3), 334-346.

8. Hanushek, EA (2005). Policy Analysis: Is It, or Could It Be, the Fifth Estate? Spencer Foundation Distinguished Lecture in Education Policy and Management Presented at the Fall Research Conference of the Association for Public Policy Analysis and Management. Washington, DC. November, 5.

9. Harris, A. (2001). Building the capacity for school improvement. School Leadership \& Management, 21(3), 261-270.

10. Hasanah, A. (2012). Teacher professional development. Jakarta: Faithful Library.

11. Jihad, A. (2013). Becoming a professional teacher: Strategies to improve teacher qualifications and quality in the global era. Jakarta: Erlangga.

12. Mead, LM (2013). Teaching public policy: Linking policy and politics. Journal of Public Affairs Education, 19(3), 389403.

13. Mostofa, M. (2007). Efforts to develop teacher professionalism in Indonesia. Journal of Economics and Education, 4(1), 17245.

14. Petrie, K., \& McGee, C. (2012). Teacher professional development: Who is the learner? Australian Journal of Teacher Education, 37(2), 4.

15. Sobri, AY (2016). Teacher Professionalism Development Models. Policy Directions for Teacher Education in Indonesia (Proceedings). VIII National Education Convention (KONASPI), ALPTKNI.

16. Sudrajat, A. (2013). Scientific Scientific Approach in the Learning Process. Available Online Https://Akhmadsudrajat. WordPress. Com/2013/07/18/Approach-Scientific-In-Process-Learning/Comment-Page-1/ (Accessed on March 10, 2014).

17. Timperley, H., Wilson, A., Barrar, H., \& Fung, I. (2007). Teacher professional learning and development: Best evidence synthesis iteration. Ministry of Education.

18. Wahab, SA (2012). Policy analysis: from formulation to formulation of public policy implementation models. Jakarta: Earth Literacy, 77.

19. Wahyudi, TN (2016). The role of education personnel education institutions (LPTK) in promoting learning teachers to improve teacher professionalism.

Cite this Article: Teti Nurhidayah, Hasan Hariri, Riswanti Rini, Sowiyah, Alifa Soraya Nuryadika (2021). The Development of the Quality of Indonesian Educators through Professional Teachers: A Literature Review. International Journal of Current Science Research and Review, 4(7), 706-710 